\title{
The Relationship between Protean Career Orientation and Perceived Employability: A Study of Private Sector Academics of Pakistan
}

\author{
Junaid Zafar * $\quad$ Mariam Farooq ${ }^{\dagger} \quad$ Muhammad Umer Quddoos ${ }^{\ddagger}$
}

\begin{abstract}
This study investigated the effect of protean career orientation on individual's perceived employability. This is the first study of its nature which tried to establish the relationship between protean career orientation and perceived employability. We used protean career theory to develop our conceptual framework. Data were collected from the academic staff of private sector universities by using the stratified sampling technique. Theoretical model was tested using the data obtained from 192 respondents. Measurement model is tested by using the confirmatory factor analysis. To test our hypothesized model, we employed structural equation modelling technique in AMOS 21. The researcher found a statistically significant relationship between protean career orientation and perceived employability. This study also provides the implications for the management.
\end{abstract}

Keywords: Protean career orientation, private education sector, perceived employability, quantitative research.

\section{Introduction}

It is important to mention that career concepts like protean career orientation and perceived employability are new terms for Pakistani researchers, and are more prevalent in the developed economies. From the perspective of the United States of America (USA), for example, there has been a transition of careers in academia taking inspiration from and having turned towards a corporate direction, as universities have become consumer driven and business orientated (Baruch \& Hall, 2004). According to Baruch and Hall (2004), a high level of autonomy (or "freedom") that is a hallmark of protean career has always been part of the university culture. Academics function like "free agents", and have a transactional contract with the university employers.

Protean career orientation, however, relates to skill development which leads to perceived employability (De Vos \& Soens, 2008; Kuijpers, Schyns, \& Scheerens, 2006; Segers, Inceoglu, Vloeberghs, Bartram, \& Henderickx, 2008). A discouraging figure, meanwhile, has been put fourth by the Bureau of Emigration and Overseas Employment (BEOE, 2015). The Bureau states that 2.5 million career dissatisfied Pakistanis have exited the country over the last five years, out of which 975 are teachers who left in 2014 alone. This trend,

\footnotetext{
* Assistant Professor, Department of Commerce, Bahauddin Zakariya University, Multan.

E-mail: jonaidzafar@gmail.com

$\dagger$ Assistant Professor, University Of Central Punjab.

E-mail: mariam.farooq@ucp.edu.pk

‡Assistant Professor, Department of Commerce, Bahauddin Zakariya University, Multan.
} 
meanwhile, has been increasing by the year, and is similar to almost all professions. It is important for the researcher to find out whether current academics at the present time feel employable and believe that their chances of getting better employment are good enough. Therefore, the perceptions of getting a job of equal or better prospects are a relevant concept to study in the modern career landscape. Also, according to De Vos, De Hauw, and Van der Heijden (2011); Van der Heijden, de Lange, Demerouti, and Van der Heijde (2009), protean career orientation helps individuals in times of economic, organizational and employment hardships maintain their employability. As such, Pakistan offers an interesting research context, especially after the Global Financial Crisis of 2007-2012, and from a Pakistani perspective. The Pew Global research poll done right after the financial crisis states: "Roughly nine-in-ten Pakistanis believe the country is on the wrong track, and about eight-in-ten say the economy is in poor shape" (Global, 2015).

Thus protean career orientation (PCO) needs to be studied in relation to perceived employability and from a Pakistani perspective as the implementation of career models in institutional environments having different social, cultural and political norms, results in diverse patterns of career development (Briscoe \& Hall, 2006). The application of AngloAmerican management techniques in non-Western countries like Pakistan leads to conflict of values and complex patterns of "hybridization" where both Eastern and Western values accommodate each other (Gamble, 2003).

This study contributes to the literature at two levels. Firstly, it developed the relationship of protean career orientation and perceived employability. Protean orientation is a new concept in management sciences as it was not studied much in the from management perspective. Secondly, this study is conducted in the south Asian context which is sharply different from the western culture in its cultural values, economic conditions and environment. This study used the unique data set of higher education in Pakistan, which provided the significant implications for the academicians and management scholars.

\section{Literature Review}

Protean career orientation has been defined by Briscoe and Hall (2006) as a: "Career concept that encompasses the extent to which he or she demonstrates self-directed and valuedriven career orientations in their personal career management" (Briscoe \& Hall, 2006). It is important to mention that with the advent of protean career orientation, and the breakdown of the "traditional career model", continuous learning has become a sine qua non for the protean careerist. Employees in traditional employment settings show loyalty towards one employer (Briscoe, Hall, \& DeMuth, 2006). In return, the employing organization rewards the employees in the form of promotions, pay increases, increased power, and greater responsibility. Employees thus are able to stay in one organization for their entire lifetime.

Furthermore, internal and external environments contribute to the self-directedness of a person (Hay \& Hodgkinson, 2006; Joseph, Boh, Ang, \& Slaughter, 2012). Thus, there is a complex interplay of environmental conditions which affect the person driven by a protean career. These environmental conditions can be taken as globalization, knowledge- 
intensive economies, the advent of technology, right-sizing or downsizing of the organizations, competitive pressures, work-life balance, decentralization, decreased job security, increase of workplace diversity, expanding outsourcing and increase in temporary or part-time workers (Briscoe \& Hall, 2006; Joseph et al., 2012; Rothwell \& Arnold, 2007).

On the other hand, Perceived employability has been defined as "The individual's beliefs about the possibilities of finding new, equal, or better employment" (De Cuyper, Mauno, Kinnunen, \& Mäkikangas, 2011). When labor market shows signs of flexibility and unpredictability, the perceptions to be employed becomes even more significant. Therefore, perceived employability is the appraisal of one's possibilities of getting new and better employment (Rothwell \& Arnold, 2007).

The term perceived employability has evolved over time. For a long time, employees considered moving vertically up the hierarchy as the preferred way to objective career success (Rothwell \& Arnold, 2007). However, with the changes taking place in the form of restructuring, downsizing and right sizing, employees are not sure of their working status in the organization. In some organizations, permanent employment has been replaced by temporary or contractual employment. The term "employability" has been introduced as a result of the changes occurring in the marketplace, and was considered in the 1950s and 1960s as the individual's ability to become employed in the labor market (Fugate, Kinicki, \& Ashforth, 2004). Employability has thus become the worker's attitude towards employment, and the self-perceptions held during one's career lifetime. Employees, who hold a positive attitude towards employment prospects with regard to their knowledge, skills, and abilities (KSA's), are seen as successful in re-entering the labor market.

\section{Hypothesis Development}

The world of work in the contemporary era is being affected by various factors, for instance, globalization, technological advancements, and recession all of which have emerged as a result of the upheavals in the economy (Briscoe \& Hall, 2006; Joseph et al., 2012; Rothwell \& Arnold, 2007). According to Sullivan and Arthur (2006) careers of today are increasingly becoming haphazard and discontinuous. Traditional career models, though existing side-by-side with contemporary models, have yielded less career success. In contemporary career models, the worker is seen as self-reliant and takes full responsibility for career development.

So, it can be held that the very nature of work has "shifted dramatically since the days of the corporate career", when the organization was in charge of the employees (Briscoe \& Finkelstein, 2009). As organizations continue to restructure, outsourcing, and downsizing; there has been an emphasis by the employees in the short-term, by becoming more flexible rather than achieving job security over the long-run. These changes taking place in the economy have transformed the career process. Previously, employment was marked by steady upward movements and loyalty shown towards the employer (Forrier \& Sels, 2003; Joseph et al., 2012). Nowadays, there is no guarantee of being employed with one organization for a lifetime. Thus, employees try to self-manage their careers through making themselves employable in the labor market (Grimland, Vigoda-Gadot, \& Baruch, 2012). The employability of the person thus depends on being flexible and adaptable so 
as to meet the new challenges in the economy.

As discussed above, the sole responsibility for developing the competencies is on the individual. Similarly, according to De Vos and Soens (2008), it is through PCO that individuals develop these competencies by self-managing and subsequently achieving perceived employability. Also, it is through protean careers that individuals value freedom and personal growth. Protean careerists are quick to adapt and reshape themselves according to the current market conditions (Hall, 2002). Employers, meanwhile, are seen as independent, and moving among different functions, organizations and industries, and breaking down the traditional assumptions of a career. An individual following a protean career thus incorporates the interests, relationships, and personal values outside the current workplace (Cabrera, 2007).

For instance, it is through being self-employable that the skills learnt are no longer firm specific; rather, they are adaptable, and transferable. Training, for instance, is not acquired through formal training programmes financed by the employer, but is more off-the-job, and hands-on. Similarly, perceived employability calls for goals to be set not according to the professional's age, but according to the capabilities, and skills of the individual (Segers et al., 2008; Volmer \& Spurk, 2011; Zikic, Novicevic, Harvey, \& Breland, 2006). It is interpreted that individuals driven by strong protean career orientations have control over themselves and engage in career self-management activities to build upon social and human capitals. Literature on protean career orientation by Enache, Sallan, Simo, and Fernandez (2011); Fugate et al. (2004); Hind (2005) establish the fact that protean careerists are driven by career-related competencies so as to maintain employability.

Furthermore, in a survey by De Vos and Soens (2008) on 289 Belgian employees who had received career counseling training, it was found that protean career was related to perceived employability. Waters, Briscoe, Hall, and Wang (2014) revealed that protean career orientation had a positive correlation with finding reemployment that is a precursor to career growth. According to Waters et al. (2014), PCO helps a person to express the values during times of unemployment and to retain a sense of identity despite being unpaid for so long.

Another study by Briscoe, Henagan, Burton, and Murphy (2012) also found a positive relationship between protean attitude and employees developing career skills that help to cope with uncertain work situations. The study was carried out on 362 employed workers in the United States during the Global Recession of 2007-2012. Therefore, it is hypothesized that: ability.

$H_{0}$ : There is a positive relationship between protean career orientation and perceived employ-

\section{Methodology}

In 2014, 194 respondents from 35 'W' category private universities filled up the questionnaires with a response rate of $55 \%$. The Higher Education in Pakistan has divided the private universities into " $\mathrm{W}$ " and "non- $\mathrm{W}$ " categories. In the " $\mathrm{W}$ " category, all private universities fulfill minimum requirements as set out by the HEC to select faculty mem- 
bers, admit students and to award degrees. While, in the "non-W" cadre there are several quality shortcomings such as the presence of part-time academics rather than full-time academics, a lack of infrastructure for research and/or degrees not recognized by the HEC.

The researcher also brought proportionate stratified sampling to use. It was to ensure that all academics under consideration have an equal chance of representation. It was also done to remove chances of biasness towards any particular rank. Therefore, various strata that are there in the study are based on job rankings. To be more specific these ranks were as follows: lecturers, assistant professors, associate professors and professors. This stratification was similar to the other studies conducted by (Qayyum et al., 2013; Oshagbemi, 2000).

\section{Measure of Protean Career Orientation}

Protean career orientation is measured using the "protean career orientation scale" (PCOS) developed by Bridgstock (2007). The researcher has decided to adopt the present instrument from Bridgstock (2007) since it measures on a single dimension of protean career orientation, has six questions and is thus more respondent friendly. It also has an excellent internal reliability with an alpha value of $\alpha=.85$. The instrument is measured on a six point Likert scale from $1=$ Strongly Disagree to $6=$ Strongly Agree .

\section{Measure of Perceived Employability}

Perceived employability (PE) is the belief of individuals about the easiness of finding new employment. The scale to measure PE is adopted from De Cuyper et al. (2011). The instrument is measured on a seven point Likert scale from 1= Strongly Disagree to $7=$ Strongly Agree and has an excellent reliability value of $\alpha=.85$ in Sample 1 and $\alpha=.80$ in Sample 2 when used by De Cuyper et al. (2011) in their experiment.

\section{Data Analysis and Results}

\section{Validity and Reliability of Measures}

Content reliability is used to determine the hypothesized relationships and to know whether they measure the constructs or not (Hair, Anderson, Babin, \& Black, 2010). For this purpose, the researcher did a critical evaluation of all the items' reliability to find out their loadings or the correlations between the hypothesized constructs. The Cronbach alpha value of .70 has been suggested by Nunnally and Bernstein (1994) while some researchers point to a lower figure of .60 (Hair \& Joseph, 2006). We found the Cronbach Alpha value of Protean career orientation (0.77) and perceived employability (0.63) is greater than the recommended value of 0.60 (Hair \& Joseph, 2006).

We performed confirmatory factor analysis and calculated the convergent validity. The measurement model produced good fit at different indices $(X 2=38.73, \mathrm{DF}=26, \mathrm{X} 2 / \mathrm{DF}=$ 
$1.49, \mathrm{CFI}=.95, \mathrm{TLI}, .91, \mathrm{RMSEA}=.06)$. Convergent validity is often used in behavioral sciences, and has been defined as testing the constructs that are expected to be related are, in fact, related (Hair et al., 2010). Both convergent validity and discriminant validity are subtypes of construct validity. Construct validity is thus the degree to which an experiment stays true to or measures what it claims (Hair et al., 2010). Convergent validity has been measured with the help of average variance extracted. The average variance extracted of perceived career orientation is 0.38 , and perceived employability is .38 . To establish the discriminant validity, it is necessary the AVE of every variable should be greater than its inter construct squared correlations. The Table 1 showed that the AVE value of Protean career orientation and perceived employability are greater than their squared correlations.

Table 1

Reliability, Convergent Validity and Discriminant Validity Analysis

\begin{tabular}{lccc}
\hline Variable & $\mathbf{1}$ & $\mathbf{2}$ & $\alpha$ \\
\hline Protean Career Orientation & $\mathbf{0 . 3 8}$ & & 0.77 \\
Perceived Employability & 0.1 & $\mathbf{0 . 3 8}$ & 0.63 \\
\hline Note: The bold values are AVE, to establish the \\
discriminant validity, AVE should be greater than \\
inter construct squared correlations.
\end{tabular}

Hypothesis testing and data analysis were initiated as soon as the questionnaires were received. It was done by using the statistical tools like Analysis of Moment Structures (AMOS) version 18 and Statistical Package for the Social Sciences (SPSS) version 18. In order to find the missing data, normality, outliers and non-respondent bias, SPSS was used while; AMOS was used to test the hypotheses and perform confirmatory factor analysis.

Figure 1

Structural Model

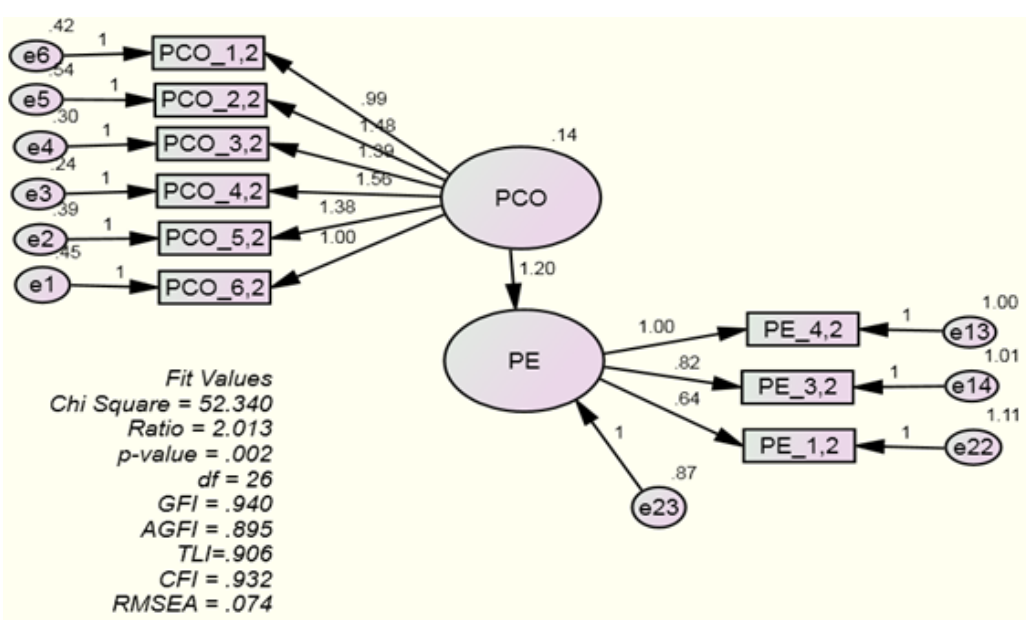

A structural model is the correlation and causal links between the latent constructs 
(Hair et al., 2010). The structural model (SM) is the last stage in structural equation modeling after the individual constructs have been defined, an overall measurement model has been developed, and measurement model validity has been assessed. Therefore, the structural model assigns relationships from one construct to another based on the hypothetical model that has been proposed in the earlier study.

Tucker Lewis index or non framed fit index; the root means squared approximation of error and comparative-fit-index, for finding the fitness of the model have been proposed (Garver \& Mentzer, 1999). Moreover, non-normed fit index (NNFI), $x^{2} /$ Degrees of Freedom ratio, root mean square error approximation (RMSEA) comparative fit index (CFI) and, additional measures that are being used to check the fitness of the model include goodness-of-fit index (GFI) and adjusted goodness-of-fit index (AGFI) (Sivo, Fan, Witta, \& Willse, 2006). In the present model, the researcher has found the following values of indices.

\begin{tabular}{lcc}
$\begin{array}{l}\text { Table } 2 \\
\text { Model Fit }\end{array}$ & \\
\hline Index & Ideal Fit & Observed Fit \\
\hline Tucker Lewis Index (TLI) & $>.90$ & 0.9 \\
Root Mean Square Approximation of Error (RMSEA) & $<.08$ & 0.07 \\
Comparative Fit Index (CFI) & $>.90$ & 0.93 \\
$X^{2}$ / D.F. ratio & Equal to or Less than 3 & 2 \\
Goodness-of-fit Index (GFI) & $>.90$ & 0.94 \\
Adjusted Goodness-of-fit Index (AGFI) & $>.80$ & 0.89 \\
\hline
\end{tabular}

The structural model describes the direct effects as one that goes directly from a variable to another within the hypothesized model. The results of the direct relationship are shown below:

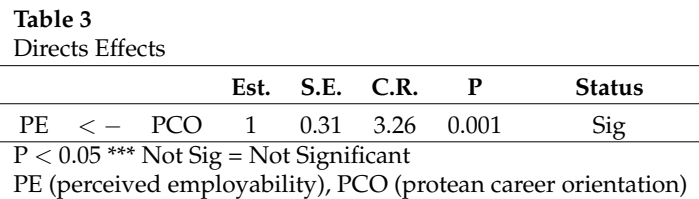

Hypothesis of the study stated that, there is a positive and statistically significant relationship between protean career orientation and perceived employability. The relationship between the two variables has been found to be statistically significant as $\beta=1.000$, $\mathrm{z}$-value $=3.26$ and $\mathrm{p}<.05$. So the hypothesis is accepted.

\section{Discussion}

A quick recapitulation of protean career orientation affecting the ability to acquire employability perceptions would lead this study into critically discussing hypothesis two. For hypothesis two (H2), this study has been hypothesized that: there is a positive relationship between protean career orientation and perceived employability. It is found there is a statistically significant relationship between the two variables as $\beta=1.000$, $\mathrm{z}$-value $=$ 
3.26 and $\mathrm{p}<.05$. Or in other words the extent to which academics display protean career orientation is added to employment prospects.

The significant relationship between protean career orientation and perceived employability is due to the complex interplay of external environmental conditions that contribute to employability. These conditions have been mentioned by Briscoe and Hall (2006); Joseph et al. (2012); Rothwell and Arnold (2007) as globalization, knowledgeintensive economies, technological advancements, work-life balance, decentralization, decreased job security, increase in workplace diversity, expanding outsourcing and increase in temporary or part-time workers. All of these fulfill the personal learning of the employees, and add to the perceived employability of the academics. Besides, the individual is also affected by changes in behaviors and attitudes: increase in life expectancy, more professional commitment towards the careers and the organizations, changed family structures with dual-career-couples, more females entering the workforce, single-working parents, and an inclination of professionals towards training, growth and development.

The statistically significant relationships between the two variables affirms the view of Joseph et al. (2012) who describe the economic recession of 2007-2012 as a lesson for workplaces to be more flexible with emphasis on skill development. Of interest is that the academics in the private sector of the country have thus been affected by factors such as globalization. Likewise, Hall (2002) called for internalizing career success in times of economic uncertainties. The present research thus points towards an emphasis by academics on learning and adapting according to changing workplace by shifting the motivations from being an employer-orientated to career-orientated. The findings of the present study, also agree with O'Neil, Bilimoria, and Saatcioglu (2004); Rothwell and Arnold (2007) that there have been changes in the psychological contract, whereby the individuals' responsibility for career development has increased.

The academics can thus enhance their perceptions of employability through an increased possession of knowledge, skills and abilities (KSA's). The perceptions of employability include "career identity" that can influence the academics" adaptations and aspirations. Academics can infuse their scientific knowledge with entrepreneurial activities so as to continue their scientific work, and thus can become an active member of the organization. This can be done through commercializing their projects through research and innovation. The findings support De Vos et al. (2011) who claim that perceived employability is taken as a human capital variable. And, according to human capital theory, employees invest in skills, which leads them to greater employability in the marketplace (Ackah \& Heaton, 2004; Ang, Slaughter, \& Yee Ng, 2002; Benson, 2006; Briscoe \& Finkelstein, 2009; Bridgstock, 2007; De Vos et al., 2011). The present study agrees with De Vos and Soens (2008) that it is through protean career orientation whereby individuals develop competencies by self-managing, and subsequently achieve employability. According to Cabrera (2007), a protean career has the individual incorporating the interests, relationships, and personal values outside the current workplace.

An interesting finding of the present study is that the academics are learning skills that are no longer firm specific; rather, they are adaptable, and transferable. These skills might include collaborative learning, problem-based learning, and case study methodol- 
ogy. Thus, academics with high employability have assets (e.g., Abilities, skills, knowledge and attitudes), which are held in esteem by the employer as they are valued and needed in the labor market. Thus these academics have something to offer to the employers, which makes them secure on the labor market; they are capable of copping up with the haphazard and chaotic labor market and today's requirement for flexibility.

Employability thus calls for academics to become more proactive with respect to their careers (Segers et al., 2008; Volmer \& Spurk, 2011). The significant relationship symbolizes academics engaging in career self-management activities to build upon social and human capitals. The study supports various literature on protean career orientation by Enache et al. (2011); Fugate et al. (2004); Hind (2005) and depicts careerists driven by career competencies. The findings are convergent with those of Waters et al. (2014) who reveal protean career orientation having a positive correlation with finding reemployment, and is a precursor to career growth. The positive relationship supports the theory of protean career, which states that individuals are driven by protean career orientation, and adapt to the various performances and learning demands (Ryan \& Deci, 2000).

\section{Theoretical and Practical Implications}

Academics are somewhat PCO driven and engage in career self-management activities so as to build upon social and human capitals. The findings are in congruence with those of Joseph et al. (2012); O'Neil et al. (2004); Rothwell and Arnold (2007) who describe external environmental conditions like recession, globalization and trade barriers impacting the world of work. This also means that the employees of the private sector, especially the academics are trying their best to keep up-to-date and afloat in a competitive everchanging environment. The study has shown that the academics working in the private educational sector of Pakistan are working in an innovative, flexible, and insecure environment where they have the capacity to showcase their knowledge skills, abilities and opportunities.

The significant relationship also points to academic careers as being unique and an academic considered an "autonomous professional" who takes on the responsibility of self-development. This is similar to the view of Baruch and Hall (2004). The findings reveal that the academics are self-directed as well as value-driven in their careers. An important finding is that the presence of a "new career" attitude is transforming the psychological contract among the academics from relational psychological to transactional psychological and, therefore, greater perceived employability is taking place.

Therefore, proactivity is shown on behalf of the academics where protean career influences perceived employability. This relationship goes a long way towards improving job performance and career outcomes. The self-identity part as present in the two variables of protean career and employability, takes the form of action or proactive orientation that helps the employees to alter the job situations to suit their own needs. This engagement in the work environment also reduces the anxiety and uncertainty inherent in the external and internal conditions. Moreover, the efforts as shown by the academics to procure their own personal ambitions can or cannot go against the organizational goals. 


\section{Limitations}

Though the researcher has tried his best to fill in the theoretical, methodological and practical gaps related to the academics' career satisfaction and protean career orientation, the study is not perfect and has several limitations. These limitations are given below: Due to time constraints, the study focused on academics in the private sector. A more thorough research could be conducted if both private and public sector, academics were chosen by the researcher. The second limitation is the cross-sectional nature of the study. The third limitation is that present study applies only to one dimension of career success, i.e. subjective career success. The fourth limitation is the use of only quantitative research methods for study. The fifth limitation of the study is that no mediating relationship has been observed in a "collectivistic" county like Pakistan. As most of the researches on the "new career" concept are from the perspective of more liberal developed economies like those of USA, United Kingdom and the European Union, future studies can take an international perspective by taking into consideration the career success of academics working in two or more countries. The sixth limitation is that the present study is based on selfreports, i.e., it has asked the respondents directly through the use of questionnaires. This may inflate the relationships that exist among the phenomena being studied, and chances of common method bias can become obvious. 


\section{References}

Ackah, C., \& Heaton, N. (2004). The reality of 'new' careers for men and for women. Journal of European Industrial Training, 28(2/3), 141-158.

Ang, S., Slaughter, S., \& Yee Ng, K. (2002). Human capital and institutional determinants of information technology compensation: Modeling multilevel and cross-level interactions. Management Science, 48(11), 1427-1445.

Baruch, Y., \& Hall, D. T. (2004). The academic career: A model for future careers in other sectors. Journal of Vocational Behavior, 64(2), 241-262.

Benson, G. S. (2006). Employee development, commitment and intention to turnover: A test of 'employability' policies in action. Human Resource Management Journal, 16(2), 173-192.

BEOE. (2015). Bureau of emigration and overseas Pakistanis. Retrieved from http://www . beoe.gov.pk/migrationstatistics.asp

Bridgstock, R. S. (2007). Success in the protean career: A predictive study of professional artists and tertiary arts graduates (Unpublished doctoral dissertation). Queensland University of Technology.

Briscoe, J. P., \& Finkelstein, L. M. (2009). The 'new career' and organizational commitment: Do boundaryless and protean attitudes make a difference? Career Development International, 14(3), 242-260.

Briscoe, J. P., \& Hall, D. T. (2006). The interplay of boundaryless and protean careers: Combinations and implications. Journal of Vocational Behavior, 69(1), 4-18.

Briscoe, J. P., Hall, D. T., \& DeMuth, R. L. F. (2006). Protean and boundaryless careers: An empirical exploration. Journal of Vocational Behavior, 69(1), 30-47.

Briscoe, J. P., Henagan, S. C., Burton, J. P., \& Murphy, W. M. (2012). Coping with an insecure employment environment: The differing roles of protean and boundaryless career orientations. Journal of Vocational Behavior, 80(2), 308-316.

Cabrera, E. F. (2007). Opting out and opting in: Understanding the complexities of women's career transitions. Career Development International, 12(3), 218-237.

De Cuyper, N., Mauno, S., Kinnunen, U., \& Mäkikangas, A. (2011). The role of job resources in the relation between perceived employability and turnover intention: A prospective two-sample study. Journal of Vocational Behavior, 78(2), 253-263.

De Vos, A., De Hauw, S., \& Van der Heijden, B. I. (2011). Competency development and career success: The mediating role of employability. Journal of Vocational Behavior, 79(2), 438-447.

De Vos, A., \& Soens, N. (2008). Protean attitude and career success: The mediating role of self-management. Journal of Vocational Behavior, 73(3), 449-456.

Enache, M., Sallan, J. M., Simo, P., \& Fernandez, V. (2011). Career attitudes and subjective career success: Tackling gender differences. Gender in Management: An International Journal, 26(3), 234-250.

Forrier, A., \& Sels, L. (2003). The concept employability: A complex mosaic. International Journal of Human Resources Development and Management, 3(2), 102-124.

Fugate, M., Kinicki, A. J., \& Ashforth, B. E. (2004). Employability: A psycho-social construct, its dimensions, and applications. Journal of Vocational Behavior, 65(1), 14-38. 
Gamble, J. (2003). Transferring human resource practices from the United Kingdom to China: The limits and potential for convergence. International Journal of Human Resource Management, 14(3), 369-387.

Garver, M. S., \& Mentzer, J. T. (1999). Logistics research methods: Employing structural equation modeling to test for construct validity. Journal of Business Logistics, 20(1), 33-57.

Global, P. (2015). On the eve of elections: A dismal public mood in Pakistan. Emerald Group Publishing Limited. Retrieved from http://www.pewglobal.org/2013/05/ 07/on-eve-of-elections-a-dismal-public-mood-in-pakistan/

Grimland, S., Vigoda-Gadot, E., \& Baruch, Y. (2012). Career attitudes and success of managers: The impact of chance event, protean, and traditional careers. The International Journal of Human Resource Management, 23(6), 1074-1094.

Hair, J., Anderson, R. E., Babin, B. J., \& Black, W. C. (2010). Multivariate data analysis: A global perspective (Vol. 7). Pearson Upper Saddle River, NJ.

Hair, J., \& Joseph, F. (2006). Multivariate data analysis. Auflage, Upper Saddle River.

Hall, D. T. (2002). Careers in and out of organizations (Vol. 107). Sage, United Kingdom.

Hay, A., \& Hodgkinson, M. (2006). Exploring mba career success. Career Development International, 11(2), 108-124.

Hind, P. (2005). Making room for career change. Career Development International, 10(4), 268-274.

Joseph, D., Boh, W. F., Ang, S., \& Slaughter, S. (2012). The career paths less (or more) traveled: A sequence analysis of IT career histories, mobility patterns, and career success. MIS Quarterly, 36(2), 427-452.

Kuijpers, M. A., Schyns, B., \& Scheerens, J. (2006). Career competencies for career success. The Career Development Quarterly, 55(2), 168-178.

Nunnally, J. C., \& Bernstein, I. (1994). The assessment of reliability. Psychometric Theory, 3(1), 248-292.

O'Neil, D. A., Bilimoria, D., \& Saatcioglu, A. (2004). Women's career types: Attributions of satisfaction with career success. Career Development International, 9(5), 478-500.

Oshagbemi, T. (2000). Gender differences in the job satisfaction of university teachers. Women in Management Review, 15(7), 331-343.

Qayyum, C., et al. (2013). Job satisfaction of university teachers across the demographics. Bulletin of Education \& Research, 35(1), 1-15.

Rothwell, A., \& Arnold, J. (2007). Self-perceived employability: Development and validation of a scale. Personnel Review, 36(1), 23-41.

Ryan, R. M., \& Deci, E. L. (2000). Self-determination theory and the facilitation of intrinsic motivation, social development, and well-being. American Psychologist, 55(1), 68-78.

Segers, J., Inceoglu, I., Vloeberghs, D., Bartram, D., \& Henderickx, E. (2008). Protean and boundaryless careers: A study on potential motivators. Journal of Vocational Behavior, 73(2), 212-230.

Sivo, S. A., Fan, X., Witta, E. L., \& Willse, J. T. (2006). The search for 'optimal' cutoff properties: Fit index criteria in structural equation modeling. The Journal of Experimental Education, 74(3), 267-288. 
Sullivan, S. E., \& Arthur, M. B. (2006). The evolution of the boundaryless career concept: Examining physical and psychological mobility. Journal of Vocational Behavior, 69(1), 19-29.

Van der Heijden, B. I., de Lange, A. H., Demerouti, E., \& Van der Heijde, C. M. (2009). Age effects on the employability-career success relationship. Journal of Vocational Behavior, 74(2), 156-164.

Volmer, J., \& Spurk, D. (2011). Protean and boundaryless career attitudes: Relationships with subjective and objective career success. Journal for Labour Market Research, 43(3), 207-218.

Waters, L., Briscoe, J. P., Hall, D. T., \& Wang, L. (2014). Protean career attitudes during unemployment and reemployment: A longitudinal perspective. Journal of Vocational Behavior, 84(3), 405-419.

Zikic, J., Novicevic, M. M., Harvey, M., \& Breland, J. (2006). Repatriate career exploration: A path to career growth and success. Career Development International, 11(7), 633649. 